Pathiranage Y.L., Jayathilake L.V.K., Abeysekara R. Wayamba Journal of Management 12 (2)

\title{
Exploring Strategies to Establish an Effective Organizational Culture to Enhance Corporate Performance: A Concept Paper
}

\author{
Y.L. Pathiranage ${ }^{1}$, L.V.K. Jayatilake ${ }^{2} \&$ R. Abeysekera $^{3}$ \\ ${ }^{1}$ Faculty of Graduate Studies \\ University of Kelaniya \\ SRI LANKA
}

${ }^{2,3}$ Faculty of Commerce and Management Studies

University of Kelaniya

SRI LANKA

pathiranage@gmail.com¹, lakminij@kln.ac.lk², ruwanab@kln.ac.lk ${ }^{3}$

\begin{abstract}
Maintaining an effective organizational culture within the corporate group is indeed a must to enhance organizational performance and shareholder return. A concept is proposed for a qualitative study aimed to explore prominent strategies that one corporate group deploys to establish an effective organizational culture to enhance performance. Denison organizational culture model is served as the theoretical underpinning for the study. "What strategies do senior managers deploy to establish an effective organizational culture to enhance performance" is identified as the research problem of the study in order to bridge the prevailing research gap. The research problem is answered through four research questions. An exploratory single-case study design is used for the study. A purposive sample of 20 senior managers from a leading corporate group in Sri Lanka participate in semi structured face-toface interviews. The study corporate group has 47 companies belongs to six main sectors, which is one of the largest corporate groups in Sri Lanka. The chosen participants conform the criteria of a minimum of 5 years of experience with strategies in establishing an effective organizational culture in the corporate group. The findings of this study would reveal a new model for business managers to enhance corporate performance by establishing an effective organizational culture.
\end{abstract}

Keywords-: Concept Paper, Corporate Group, Corporate Performance, Organizational Culture 


\section{INTRODUCTION}

Organizational culture can be considered as an indispensable element of organizational performance, and also a source of sustainable competitive advantage (Childress, 2013; Kenny, 2012). In a corporate group structure with diversified companies, managers have more challenges to establish an effective organizational culture (Lee \& Gaur, 2013). Lee and Gaur (2013) indicated that establishing an effective organizational culture in the corporate group is necessary to enhance performance.

This paper highlights the conceptual approach for a qualitative study of exploring the strategies that one corporate group deploys to establish an effective organizational culture to enhance performance. The paper consists of five main sections, which explain the conceptual approach of this study with academic rigor. In the first section: background of the study and analysis of the existing research gaps are explained. The second section focuses on identification of research problem and research questions according to the research objectives. In the third section: the empirical and practical significance of the study are explained. The fourth section emphasizes on the research methodology used for the study. And finally, in the fifth section: assumptions, limitations, and delimitations relate to the study are highlighted.

\section{BACKGROUND OF THE STUDY}

A corporate group or holding company business structure has been an imperative strategy for corporate growth since 1960 (Eukeria \& Favourate, 2014). A corporate group is a series of legally independent companies that operates as a single commercial entity under a common power of control, governance, and leadership (Gajewski, 2013; Kenny, 2012).

When an organization becomes more diverse, managers have more challenges to manage and control resources within the group (Kenny, 2012). Managers of the corporate group may feel the loss of control when group diversification increases (Gajewski, 2013). Managers struggle to execute and sustain their strategy without adequate organizational culture support (Eaton \& Kilby, 2015; Weber \& Tarba, 2012). Though an economic advantage can be obtained by managing diversified companies under common leadership, lack of effective organizational culture causes corporate groups to fail (Kenny, 2012; Lien \& Li, 2013). Therefore, organizational culture can be considered as an indispensable element of organizational performance, and also a source of sustainable competitive advantage.

Organizational culture is 
important to amalgamate various company cultures in the corporate group structure (Kenny, 2012). Corporate managers can establish an effective organizational culture to enhance performance (Childress, 2013; Flamholtz \& Randle, 2011; Melo, 2012). Efficacious cultural integration within the corporate group is an important element in maintaining successful communication and enhancing performance (Idris, Wahab, \& Jaapar, 2015). Lee and Gaur (2013) indicated that establishing an effective organizational culture in the corporate group is necessary to enhance performance.

Many corporate managers struggle to survive in a competitive market due to the dynamic characteristics of global business (Bolboli \& Reiche, 2014). Increasing global price competition and satisfying demands of different stakeholders are some of the key challenges faced by business managers today (Bolboli \& Reiche, 2013). In a corporate group structure with diversified companies, managers have more challenges to establish an effective organizational culture, which is an indispensable element to enhance performance (Kenny, 2012; Lee \& Gaur, 2013).

Profitability is a crucial factor for the persistence of any business, and expanding the business scope is also vital for the growth of the business (Erdorf, Hartmann-Wendels, Heinrichs, \& Matz, 2013). Poor cultural integration within diversified companies affects the financial performance of the corporate group and shareholder value (Eaton \& Kilby, 2015; Idris et al., 2015). Weber and Tarba (2012) indicated that cultural disparities that exist within the group are major obstacles to corporate performance. Bolboli and Reiche (2014) indicated that over $90 \%$ of business excellence initiatives fail to thrive due to poor cultural integration among managers in the corporate group. Therefore, it is obvious that business managers must understand the importance of establishing an effective organizational culture to enhance performance in the corporate group (Viegas-Pires, 2013).

\section{RESEARCH GAP}

This section analyses the theoretical, literature / empirical, and practice gaps for the intended study. How an effective organizational culture was established to enhance the corporate performance can be recognized as a needed research scope in the context of bridging the prevailing research gaps expressed as below.

\subsection{Theoretical gap}

Organizational culture theory involves beliefs, assumptions, and symbols of organizational 
members that define the process in which a company conducts its business. Business managers use organizational culture theory to address different business issues in the organization (Schneider, Ehrhart, \& Macey, 2013).

Nwibere (2013) indicated that a lack of theoretical support exists to advance the manager's knowledge in the area of effectiveness of organizational culture. Hartnell, $\mathrm{Ou}$, and Kinicki (2011) found a disagreement and lack of universal standardization to measure the effectiveness of organizational culture.

Flamholtz and Randle (2011) indicated that the existing organizational culture literature does not fully cover the role of culture on performance.

\subsection{Literature / Empirical} gap

Denison (1990) identified four elements of organizational culture model: involvement, consistency, adaptability, and mission, where involvement and consistency as internal factors, and adaptability and mission are external factors in maintaining an effective organizational culture. Hacker (2015) found a positive relationship between high employee involvement in the decision-making process and organizational performance. But, Givens (2012) argued that a high level of involvement in numerous activities results in a lack of specialization, and it is difficult to identify the individual responsible for the specific task. Givens (2012) identified consistency as one of the key factors for creating an effective organizational culture and enhancing organizational performance. But, Nongo and Ikyanyon (2012) argued that a high degree of consistency in the organization does not directly influence the commitment of employees and organizational performance.

There are four types of organizational culture: clan culture, adhocracy culture, hierarchy culture, and competition culture (Fiordelisi, 2014; Kim \& Chang, 2019; Sok, Blomme, \& Tromp, 2014; Wiewiora, Murphy, Trigunarsyah, \& Brown, 2014). Research findings showed how clan culture positively relates to organizational performance (Han, 2012; Man \& Luvision, 2014; Murphy, Cooke, \& Lopez, 2013). But, Givens (2012) argued that clan culture involves issues of employee relations rather than enhancing organizational efficiency and effectiveness. Hartnell et al. (2011) found a positive relationship between adhocracy culture and corporate performance in the long-term perspective. Han (2012) found a negative relationship between hierarchy culture and corporate performance.

Research findings showed that developing a positive workplace 
culture leads a performance enhancement in the organization (Fusch \& Gillespie, 2012; O'Reilly III, Caldwell, Chatman, \& Doerr, 2014; Uddin, Luva, \& Hossian, 2013). However, Childress (2013) argued that organizational culture does affect business performance positively or negatively. Unger, Rank, and Gemunden (2014) found a positive relationship between corporate culture and financial performance. Flamholtz and Randle (2012) indicated that $46 \%$ of corporate earnings are affected by the effectiveness of organizational culture. However, Berg and Wilderom (2012) argued that the organizational culture might affect performance, where the change is a long-time interval showing the effects of culture on financial performance. While recent studies showed that organizational cultural traits and organizational performance are positively correlated (Cura, 2018; Gorondutse \& Hilman, 2019; Heris, 2014; Kohtamaki, Thorgren, \& Wincent, 2016; Nikpour, 2017; Sengottuvel \& Aktharsha, 2016; Wahyuningsih, Sudiro, Troena, \& Irawanto, 2019), a study carried by Rashid and Shah (2016) rejected the hypothesis that stated there is a significant relationship between organizational culture and organizational performance. Moreover, Leithy (2017) argued that both work-related attitudes and work behaviour can be seen as related to organizational performance, and the structural equation model apparently eliminated the relationship between organizational culture and performance.

Empirical evidences further showed that when diversification supports with an effective organizational culture, diversified companies outperform the other companies (Gajewski, 2013; George \& Kabir, 2012; Lee \& Gaur, 2013). In contrast, other study findings showed that diversification activities show less financial return in the short-term, but high financial return and competitiveness in the long-term (Coad \& Guenther, 2013).

Though a substantial amount of literature on organizational culture includes publications since 1980 in Western countries, a gap exists in the literature in the context of developing countries (Nwibere, 2013). Moreover, in the Sri Lankan context, there were very few studies conducted so far focusing on organizational culture.

\subsection{Practice gap}

Organization's culture is an important conceptual tool that can provide useful insights into effective performance management (Landekić, Šporčić, Martinić, \& Bakarić, 2015; Taylor, 2014). Business managers may develop and maintain a positive 
organizational culture to enhance the performance in the organization (Childress, 2013; Flamholtz \& Randle, 2011; Melo, 2012). Pinho, Rodrigues, and Dibb (2014) highlighted that employees and business managers with strong organizational culture have an excellent professional quality that contributes to performance enhancement in the organization.

Weber and Tarba (2012) indicated that $89 \%$ of newly acquired businesses in the United States of America fail to succeed due to a lack of cultural integration between member companies and the corporate office. Another recent study also showed that $68 \%$ of corporate business managers in the world believe that their organizational culture does not align with their business strategy (Eaton \& Kilby, 2015). Though $72 \%$ of corporate leaders recognized the importance of organizational culture to organizational performance, only $25 \%$ identified an effective organizational culture for their organizations (Eaton \& Kilby, 2015).

In the pilot study (initial discussions had with Sector CEOs and Company GMs) carried out of the study company, it has been revealed that establishing an effective organizational culture is the key to their superior performance (Anonymous Holdings PLC,
2019). Therefore, exploring the prominent strategies that senior managers deploy to establish an effective organizational culture to enhance performance, is vital and can be recognized as a needed research scope.

\section{PROBLEM}

\section{STATEMENT}

The absence of effective organizational culture and poor cultural integration affect organizational performance and decrease shareholder return in a corporate group (Idris et al., 2015). As per Eaton and Kilby (2015), 72\% of corporate leaders recognized the importance of organizational culture to organizational performance, but only $25 \%$ identified an effective organizational culture for their organizations. The general business problem is that some company managers lack an effective organizational culture, which often leads to poor performance in the corporate group (Eaton \& Kilby, 2015; Viegas-Pires, 2013). The specific business problem is that certain senior managers in the corporate group lack strategies to establish an effective organizational culture to enhance performance (Hirsch, 2015).

\section{RESEARCH OBJECTIVES}

The main objective of this qualitative exploratory singlecase study is to explore the prominent strategies which senior managers deploy to 


establish an effective
organizational culture to
enhance performance.

The other specific objectives of this research are:

- To explore how senior managers utilize "Involvement" trait of organizational culture to enhance performance

- To explore how senior managers utilize

"Consistency" trait of organizational culture to enhance performance

- To explore how senior managers utilize "Adaptability" trait of organizational culture to enhance performance

- To explore how senior managers utilize "Mission" trait of organizational culture to enhance performance

The target population of the study is senior managers with prominent strategies in establishing an effective organizational culture in a leading corporate group from Sri Lanka. Eaton and Kilby (2015) indicated that creating and maintaining an effective organizational culture is important to enhance performance.

The findings of the study may positively support business managers by understanding the role of organizational culture and providing strategies to enhance their company performance. The public may also benefit from the existence of a productive company in many ways (Childress, 2013).

\section{RESEARCH}

\section{PROBLEM RESEARCH QUESTIONS}

AND

The research problem of the study is the following:

What strategies do senior managers deploy to establish an effective organizational culture to enhance performance?

One of the essential criteria in choosing a research method is specifying an appropriate research problem for the study (Yin, 2014). Exploratory qualitative research problems include "what", "how", and "why" questions. Yin (2014) indicated that research problems which start with "what", "how", and "why" terms are appropriate for an exploratory case study. The research problem is important to guide the study and to explore the role of organizational culture in the corporate group.

The study includes four research questions to collect relevant information to answer the research problem as follows:

1. How do senior managers utilize "Involvement" trait of organizational culture to enhance performance? 
2. How do senior managers utilize "Consistency" trait of organizational culture to enhance performance?

3. How do senior managers utilize "Adaptability" trait of organizational culture to enhance performance?

4. How do senior managers utilize "Mission" trait of organizational culture to enhance performance?

\section{SIGNIFICANCE OF THE STUDY}

The promotion of business excellence in the organization depends on organizational culture and successful implementation of necessary changes in shared basic assumptions, beliefs, values, behaviour, and attitudes of employees (Bolboli \& Reiche, 2014; Kenny, 2012; Lee \& Gaur, 2013; Ruiz-Palomino \& Martínez-Cañas, 2014). Business managers may use the study results to enhance their understanding of the role of organizational culture in the corporate group (Bolboli \& Reiche, 2014). A deep understanding of the culture of an organization contributes to establish and maintain an effective organizational culture throughout the organizational system, which helps to enhance performance in the corporate group (Raza, Anjum, Shamsi, \& Zia, 2014).

The study results may contribute to expand the body of knowledge regarding the organizational culture and organizational performance as there were very few studies conducted so far in the Sri Lankan perspective.

The study results may be useful to business managers in the corporate sector who face challenges of enhancing performance for their organizations. Moreover, this study would reveal a new model for business managers to enhance corporate performance by establishing an effective organizational culture. Cura (2018) indicated that $25 \%$ of performance is affected by organizational cultural traits, and therefore cultural enhancing will result in performance enhancement by $25 \%$.

\section{METHODS}

An induction research logic is considered for the study since it focuses on theory building in the area of organizational culture (Creswell, 2007; Gill \& Johnson, 2002; Saunders, Lewis, \& Thornhill, 2007). A qualitative method is used to explore the role of organizational culture in the study company since qualitative methods are suitable to explore the intended phenomenon in a study, especially in studying individual and group behaviour in an organization (Tsang, 2014; Yin, 2014).

Case study research design is used for the study since it investigates a contemporary 
phenomenon of organizational culture in depth and within its real-life context, it answers the "how" type of exploratory questions, and it does not control the phenomenon being studied (Yin, 2014). The exploratory case study approach is used for the study since it is suitable to explore situations and processes in the case, and it is appropriate to answer "how" type questions in the research (Poulis, Poulis, \& Plakoyiannaki, 2013). The single-case design suites the needs of the study since the study company having a history of using an effective organizational culture to enhance performance (Anonymous Holdings PLC, 2019). Yin (2014) indicated that single-case might represent the critical test of a single theory.

Face-to-face interview is used as the main data collection technique for the study since indepth interviews are useful to explore the study's phenomenon comprehensively

(Cleary, Horsfall, \& Hayter, 2014; Yin, 2014). A purposive sample of 20 senior managers from the study corporate group participates in semi-structured face-to-face interviews. The study corporate group has 47 companies belongs to six main sectors, which is one of the largest corporate groups in Sri Lanka (Anonymous Holdings PLC, 2019). The chosen participants conform the criteria of a minimum of 5 years of experience with strategies in establishing an effective organizational culture in the corporate group.

\section{ASSUMPTIONS, LIMITATIONS, AND DELIMITATIONS}

It is important to understand assumptions, limitations and delimitations related to the study in order to recognize possible threats to the research design and also to avoid chaos among readers (Connelly, 2013). The study is based on the following assumptions, limitations, and delimitations.

An assumption can be identified as a realistic expectation of a research process (Ellis \& Levy, 2009). The primary assumption of this exploratory single-case study is that the selected participants (senior managers of the corporate group) have appropriate knowledge and experience on the topic, and suited the needs of the study (Yin, 2014). The second assumption is that the participants respond honestly to the interview questions since the participation is voluntary.

Limitations include deficiencies and conditions of a research process (Connelly, 2013). The first limitation of the study is the readiness and flexibility of research participants (senior managers of the corporate group) to devote enough time to the interview due to their busy schedules. The second limitation is that the potential personal bias of research participants based on 
their long-standing experience in the company.

Delimitations relates to the scope and extent of a research process (Pemberton, 2012). The first delimitation is that some of the findings of the study might not relevant and applicable to other business managers working in different sectors. The second delimitation is exploring the role of organizational culture from a single corporate group in Sri Lanka.

\section{CONCLUSION}

Establishing an effective organizational culture in the corporate group is necessary to enhance performance. This paper proposed a conceptual approach for a qualitative study of exploring the strategies that one corporate group deploys to establish an effective organizational culture to enhance performance. The focus was confined to: background of the study, analysis of the existing research gaps, identification of research problem and research questions according to the research objectives, empirical and practical significance of the study, research methodology, assumptions, limitations, and delimitations relate to the study. The proposed conceptual approach was well argued with academic rigor in order to extend it towards a doctoral study which would reveal a new model for business managers to enhance corporate performance by establishing an effective organizational culture.

\section{REFERENCES}

Anonymous Holdings PLC (2019). 2018-2019 Annual Report.

Berg, P., \& Wilderom, C. (2012). A longitudinal study of the effects of charismatic leadership and organizational culture on objective and perceived corporate performance. The Leadership Quarterly, 23, 835-848.

Bolboli, S., \& Reiche, M. (2013). A model for sustainable business excellence: Implementation and the roadmap. The TQM Journal, 25, 331-346.

Bolboli, S., \& Reiche, M. (2014). Culture-based design and implementation of business excellence. The TQM Journal, 26, 329-347.

Childress, J. R. (2013). Leverage: The CEO's guide to corporate culture [Kindle Edition version]. Retrieved from http://www.amazon.com

Cleary, M., Horsfall, J., \& Hayter, M. (2014). Data collection and sampling in qualitative research: Does size matter? Journal of Advanced Nursing, 70, 473475.

Coad, A., \& Guenther, C. (2013). Diversification patterns and survival as firms mature. Small Business Economics, 41, 633-649. 
Connelly, L. (2013). Limitation section. MedSurg Nursing, 22, 325-326. Retrieved from

http://www.medsurgnursin g.net

Creswell, J. (2007). Qualitative inquiry research design: choosing among five approaches ( $2^{\text {nd }}$ Ed.). Thousand Oaks, CA: Sage.

Cura, F. (2018). Impact of organizational culture on organizational

performance: Northern Iraq Private Universities. International Journal of Pure and Applied Mathematics, 118(20), 4843-4859.

Denison, D. R. (1990). Corporate culture and organizational

effectiveness. New York, NY: Wiley.

Eaton, D., \& Kilby, G. (2015). Does your organizational culture support your business strategy? Journal for Quality and Participation, 37(4), 4-7.

Ellis, T., \& Levy, Y. (2009). Towards a guide for novice researchers on research methodology: Review and proposed methods. Issues in Informing Science \& Information Technology, 6 , 323-337.

Erdorf, S., Hartmann-Wendels, T., Heinrichs, N., \& Matz, M. (2013). Corporate diversification and firm value: A survey of recent literature.

Financial
Markets and Portfolio Management, 27, 187-215.

Eukeria, M., \& Favourate, S. (2014). Diversification as a corporate strategy and its effect on firm performance: A study of Zimbabwean listed conglomerates in the food and beverages sector. International Journal of Economics and Finance, 6, 182-195.

Fiordelisi, F., \& Ricci, O. (2014). Corporate culture and CEO turnover. Journal of Corporate Finance, 28, 6682.

Flamholtz, E., \& Randle, Y. (2011). Corporate culture: The ultimate strategic asset. Stanford, CA: Stanford University Press.

Flamholtz, E., \& Randle, Y. (2012). Corporate culture, business models, competitive advantage, strategic assets, and the bottom line. Journal of Human Resource Costing \& Accounting, 16, 76-94.

Fusch, G. E., \& Gillespie, R. C. (2012). A practical approach to performance interventions and analysis: 50 models for building a high-performance culture. Upper Saddle River, NJ: FT Press.

Gajewski, D. (2013). The holding company as an instrument of companies' tax-financial policy formation. Contemporary Economics, 7(1), 75-82.

George, R., \& Kabir, R. (2012). Heterogeneity in business 
groups and the corporate diversification-firm

performance relationship. Journal of Business Research, 65, 412-420.

Gill, J., \& Johnson, P. (2002). Research methods for managers. London: Sage.

Givens, R. (2012). The study of the relationship between organizational culture and organizational performance in non-profit religious organizations. International Journal of Organization Theory and Behaviour, 15, 239-263.

Gorondutse, A. H., \& Hilman, H. (2019). Does organizational culture matter in the relationship between trust and SMEs performance. Management Decision, 57(7), 1638-1658.

Hacker, S. K. (2015). Leading cultural transformation. The Journal for Quality and Participation, 37(4), 13-16.

Han, H. (2012). The relationship among corporate culture, strategic orientation, and financial performance. Cornell Hospitality Quarterly, 53, 207-219.

Hartnell, C. A., Ou, A. Y., \& Kinicki, A. (2011). Organizational culture and organizational

effectiveness: A metaanalytic investigation of the competing values framework's theoretical suppositions. Journal of Applied Psychology, 96(4), 677-694.
Heris, M. S. (2014). Effects of organizational culture on organizational effectiveness in Islamic Azad universities of northwest of Iran. Indian Journal of Fundamental and Applied Life Sciences, 4(3), 250-256.

Hirsch, P. (2015). Being awkward: Creating conscious culture change. Journal of Business Strategy, 36(1), 52-103.

Idris, S., Wahab, R., \& Jaapar, A. (2015). Corporate cultures integration and organizational performance: A conceptual model on the performance of acquiring companies. Procedia - Social and Behavioural Sciences, 172, 591-595.

Kenny, G. (2012). Diversification: Best practices of the leading companies. Journal of Business Strategy, 33(1), 12-20.

Kim, T., \& Chang, J. (2019). Organizational culture and performance: a macro-level longitudinal study. Leadership \& Organization Development Journal, 40(1), 65-84.

Kohtamaki, M., Thorgren, S., \& Wincent, J. (2016). Organizational identity and behaviours in strategic networks. Journal of Business \& Industrial Marketing, 31, 36-46.

Landekić, M., Šporčić, M., Martinić, I., \& Bakarić, M. (2015). Influence of 
organizational culture on firm efficiency: competing values framework in Croatian forestry. Scandinavian Journal of Forest Research, 30(7), 624-636.

Lee, J., \& Gaur, A. (2013). Managing multi-business firms: A comparison between Korean Chaebols and diversified U.S. firms. Journal of World Business, 48, 443-454.

Leithy, W. E. (2017). Organizational Culture and Organizational

Performance. International Journal of Economics \& Management Sciences, 6(4), 442-447.

Lien, Y., \& Li, S. (2013). Does diversification add firm value in emerging economies? Effect of corporate governance. Journal of Business Research, 66, 2425-2430.

Man, A., \& Luvision, D. (2014). Sense-making's role in creating alliance supportive organizational cultures. Management Decision, 52, 259-277.

Melo, T. (2012). Determinants of corporate social performance: The influence of organizational culture, management tenure, and financial performance. Social Responsibility Journal, 8, 33-47.

Murphy, P. J., Cooke, R. A., \& Lopez, Y. (2013). Firm culture and performance: Intensity's effects and limits.

Management Decision, 51, 661-679.

Nikpour, A. (2017). The impact of organizational culture on organizational

performance:

The

mediating role of employee's organizational commitment. International Journal of Organizational Leadership, 6, 65-72.

Nongo, E., \& Ikyanyon, D. (2012). The influence of corporate culture on employee commitment to the organization. International Journal of Business and Management, 7(22), 21-28.

Nwibere, B. (2013). The influence of corporate culture on managerial leadership style: The Nigerian experience. International Journal of Business and Public Administration, 10, 166187.

O'Reilly III, C. A., Caldwell, D. F., Chatman, J. A., \& Doerr, B. (2014). The Promise and Problems of Organizational Culture: CEO Personality, Culture, and Firm Performance. Group \& Organization Management, 39(6), 595-625.

Pemberton, C. (2012). A how to guide for the education thesis / dissertation process. Kappa Delta Pi Record, 48, 82-86.

Pinho, J., Rodrigues, A., \& Dibb, S. (2014). The role of corporate culture, market orientation, and 
organizational commitment in organizational performance. Journal of Management Development, 33, 374-398.

Poulis, K., Poulis, E., \& Plakoyiannaki, E. (2013). The role of context in case study selection: An international business perspective. International Business Review, 22, 304314.

Rashid, H., \& Shah, A. B. A. (2016). Impact of Organizational Culture on Organizational

Performance: Evidence from Education Sector. Journal of Business Management and Economic Studies, 1(1), 16-30.

Raza, H., Anjum, M., Shamsi, A., \& Zia, A. (2014). The impact of culture on the perception of employees and organizational productivity in pharmaceutical industries in Karachi. Interdisciplinary Journal of Contemporary Research in Business, 5, 385-400.

Ruiz-Palomino, P., \& MartínezCañas, R. (2014). Ethical culture, ethical intent, and organizational citizenship behaviour: The moderating and mediating role of person-organization fit. Journal of Business Ethics, 120(1), 95-108.

Saunders, M., Lewis, P., \& Thornhill, A. (2007). Research methods for business students (4 ${ }^{\text {th }} \mathrm{Ed}$.). London: Prentice Hall.

Schneider, B., Ehrhart, M. G., \& Macey, W. H. (2013). Organizational climate and culture. Annual Review of Psychology, 64, 361-388.

Sengottuvel, A., \& Aktharsha, U. S. (2016). The Influence of Organizational Culture on Organizational

Performance in Information Technology Sector. IOSR Journal of Business and Management, 18(10), 5664.

Sok, J., Blomme, R., \& Tromp, D. (2014). Positive and negative spillover from work to home: The role of organizational culture and supportive arrangements. British Journal of Management, 25, 456-472.

Tarba, S. Y., Ahammad, M. F., Junni, P., Stokes, P., \& Morag, O. (2017). The Impact of Organizational Culture Differences, Synergy Potential, and Autonomy Granted to the Acquired High-Tech Firms on the M\&A Performance. Group \& Organization Management, 44(3), 483520.

Taylor, J. (2014). Organizational Culture and the Paradox of Performance Management. Public Performance \& Management Review, 38(1), 7-22.

Tsang, E. (2014). Generalizing from research findings: The merits of case studies. International Journal of 
Management Reviews, 16, 369-383.

Uddin, M., Luva, R., \& Hossian, S. (2013). Impact of organizational culture on employee performance and productivity: A case study of telecommunication sector in Bangladesh. International Journal of Business and Management, 8(2), 63-77.

Unger, B., Rank, J., \& Gemunden, H. (2014). Corporate innovation culture and dimensions of project portfolio success: The moderating role of national culture. Project Management Journal, 45(6), 38-57.

Viegas-Pires, M. (2013). Multiple levels of culture and post m\&a integration: A suggested theoretical framework. Thunderbird International Business Review, 55, 357-370.

Wahyuningsih, S. H., Sudiro, A., Troena, E. A., \& Irawanto, D. W. (2019). Analysis of organizational culture with Denison's model approach for international business competitiveness. Problems and Perspectives in Management, 17(1), 142151.

Weber, Y., \& Tarba, S. (2012). Mergers and acquisitions process: The use of corporate culture analysis. Cross Cultural Management, 19, 288-303.

Wiewiora, A., Murphy, G., Trigunarsyah, B., \& Brown,
K. (2014). Interactions between organizational culture, trustworthiness, and mechanisms for interproject knowledge sharing. Project Management Journal, 45(2), 48-65.

Yin, R. K. (2014). Case study research: Design and methods $\left(5^{\text {th }}\right.$ Ed.). Thousand Oaks, CA: Sage. 